\title{
Increased Nitrogen Availability in the Soil Under Mature Picea abies Trees Exposed to Elevated $\mathrm{CO}_{2}$ Concentrations
}

\section{OPEN ACCESS}

Edited by:

Laurent Augusto,

INRA Centre

Bordeaux-Aquitaine, France

Reviewed by:

Chao Wang,

Institute of Applied Ecology

(CAS), China

Zachary E. Kayler,

University of Idaho, United States

*Correspondence:

Patrick Schlepp

patrick.schleppi@wsl.ch

${ }^{\dagger}$ Present address:

Tamir Klein,

Department of Plant and Environmental Sciences, Weizmann Institute of Science, Rehovot, Israel

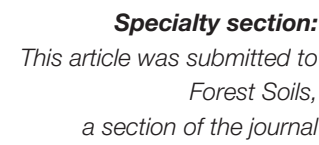
Frontiers in Forests and Global

Change

Received: 13 June 2019 Accepted: 10 September 2019 Published: 24 September 2019

Citation:

Schleppi P, Körner C and Klein T (2019) Increased Nitrogen Availability in the Soil Under Mature Picea abies

Trees Exposed to Elevated $\mathrm{CO}_{2}$ Concentrations Front. For. Glob. Change 2:59. doi: 10.3389/ffgc.2019.00059

\author{
Patrick Schleppi ${ }^{1 *}$, Christian Körner ${ }^{2}$ and Tamir Klein ${ }^{2+}$ \\ ${ }^{1}$ Department of Forest Soils and Biogeochemistry, Swiss Federal Institute for Forest, Snow and Landscape Research (WSL), \\ Birmensdorf, Switzerland, ${ }^{2}$ Department of Environmental Sciences, Institute of Botany, University of Basel, Basel, Switzerland
}

The response of trees to increasing atmospheric $\mathrm{CO}_{2}$ concentrations is often mediated by the availability of nutrients. However, little is known about the influence of $\mathrm{CO}_{2}$ enrichment on nutrient availability in forests with mature trees. We studied processes in the soil under five 35-m-tall Norway spruce trees (Picea abies) in NW Switzerland that were exposed to a mean $\mathrm{CO}_{2}$ concentration of 550 ppm for 5 growing seasons using free air $\mathrm{CO}_{2}$ enrichment (FACE). We compared them with values from the soil under five control trees. Ceramic suction cups were installed in the soil under each tree to collect soil solution, and ion-exchange resin bags were buried in the soil to absorb ammonium and nitrate. Soil cores taken at the end of the experiment were used to measure the gross production of ammonium and nitrate by the ${ }^{15} \mathrm{~N}$ dilution technique. Although temporally and spatially variable, the nitrate concentration was higher in the soil solution under $\mathrm{CO}_{2}$-enriched trees. This effect was reflected in the resin bag extracts, which additionally indicated a trend of increased ammonium availability. Dissolved reduced $\mathrm{N}$ concentration (mainly dissolved organic $\mathrm{N}$ ), however, was lower in the soil solution under $\mathrm{CO}_{2}$-enriched trees. Kand Mg, and to a lesser extent $\mathrm{Na}$ and sulfate concentrations increased in the soil solution. P concentrations mostly remained below the detection limit. In spite of the higher concentrations of nitrate in soil extracts, gross $\mathrm{N}$ mineralization and nitrification rates were not affected by FACE. Needles from $\mathrm{CO}_{2}$-enriched trees contained slightly more $\mathrm{N}$. No difference was observed for other nutrients. Overall, these results support the hypothesis of a priming effect, i.e., that FACE led to the production of more root exudates, which in turn stimulated soil biological activity, including mineralization, over a time-span of at least several years. However, these tall trees showed no growth response to elevated $\mathrm{CO}_{2}$; hence, they gained no advantage from increased nitrate in the soil solution, presumably owing to other growth constraints including $P$ and Mg availability.

Keywords: temperate forest, Picea abies, $\mathrm{CO}_{2}$ enrichment, FACE, soil solution, nitrate, nitrification

\section{INTRODUCTION}

The carbon dioxide $\left(\mathrm{CO}_{2}\right)$ concentration in the atmosphere is currently higher than ever during the last 800,000 years (Lüthi et al., 2008). While it is challenging to reliably estimate the C budget of forests, their response to the increasing atmospheric $\mathrm{CO}_{2}$ concentrations is one of the major uncertainties in predicting how terrestrial ecosystems feed back on atmospheric $\mathrm{CO}_{2}$ (e.g., 
Rollinson et al., 2017). Forests may mitigate the $\mathrm{CO}_{2}$ accumulation in the atmosphere if their area expands or if their wood stocks increase (Körner, 2017). As the availability of nutrients (defined as the amounts present in the soil and accessible for plant roots) will probably not increase in proportion to rising $\mathrm{CO}_{2}$ levels, nutrients are likely to limit the growth responses of trees to elevated $\mathrm{CO}_{2}$ concentrations (Oren et al., 2001; Körner, 2006; Sigurdsson et al., 2013). Whether terrestrial ecosystems, including forests, are sources or sinks for $\mathrm{CO}_{2}$ will ultimately depend on interactions of the $\mathrm{C}$ cycle with the cycles of nutrients, especially nitrogen $(\mathrm{N})$ and phosphorus (P) (Iversen and Norby, 2008; Ellsworth et al., 2017). Plant-mediated soil processes are thus crucial for predicting how forests will interact with global climate change.

Nitrogen $(\mathrm{N})$ and phosphorus $(\mathrm{P})$ limitation can affect the forest $\mathrm{C}$ budget by controlling the net primary production (NPP), the allocation of NPP in plants and in the ecosystem, and thereby the net ecosystem production (NEP). Among the multiple possible scenarios of interactions between $\mathrm{C}$ and nutrient cycles, enhanced photosynthesis and plant growth may consume larger amounts of nutrients, thus depleting the pool of available soil nutrients (Luo et al., 2004). Exudation of extra carbon compounds to the heterotrophic soil community may also reduce nutrient availability (e.g., Inauen et al., 2012). On the other hand, if more $\mathrm{C}$ is released by the roots (Nie et al., 2013), this surplus may increase soil biological activity and, with it, the release of nutrients by mineralization of soil organic matter (SOM) ("priming" effect; Phillips et al., 2012). In a FACE experiment in the Duke Forest (North Carolina, USA) with a young plantation of loblolly pine (Pinus taeda L.), $\mathrm{CO}_{2}$ enrichment stimulated NPP for over a decade, resulting in greater biomass accumulation (McCarthy et al., 2010). The magnitude of this increase depended on the $\mathrm{N}$ status of the single plots (McCarthy et al., 2010), and there was no enhancement at a nutrient-poorer site nearby (Oren et al., 2001). In a FACE study at the Oak Ridge National Laboratory (Tennessee, USA) in a closed canopy of sweetgum (Liquidambar styraciflua L.), an initially higher NPP translated into more fine-root production (Norby et al., 2004). This effect disappeared toward the end of this 11year experiment, but the positive effect on growth was more sustained when $\mathrm{N}$ was added as fertiliter. In a boreal forest in Flakaliden (Sweden), Norway spruce trees (Picea abies L.) did not respond to $\mathrm{CO}_{2}$ enrichment unless nutrients were added (Sigurdsson et al., 2013). In Australia, the EucFACE experiment conducted in a mature eucalypt forest (mainly Eucalyptus tereticornis) likewise showed that nutrient limitation, especially by $\mathrm{P}$, prevented $\mathrm{CO}_{2}$ enrichment to increase forest productivity. In a previous experiment in a mature mixed forest in northwest Switzerland, we showed that the growth of broadleaved trees was not enhanced by 8 years of FACE, in spite of increased photosynthesis, presumably due to limitations by nutrients other than $\mathrm{N}$, like $\mathrm{P}$ and $\mathrm{Mg}$ (Bader et al., 2010).

Overall, experiments conducted in closed-canopy forests on natural soils show very little or no growth stimulation when exposed to elevated $\mathrm{CO}_{2}$ concentrations, often as a result of nutrient limitation. While natural forest stands are usually nutrient-limited from the beginning on, young, artificial stands follow the concept of progressive nutrient limitation (PNL) proposed by Luo et al. (2004) and Johnson (2006), where the availability of nutrients, especially $\mathrm{N}$ but often also $\mathrm{P}$ limits the capacity of forests to take up more C. At the same time, however, many of these studies showed contradictory results when the availability of nutrients was assessed in the soil. At Oak Ridge (Norby et al., 2010), the uptake of $\mathrm{N}$ mineralized in deeper soil layers partly alleviated the observed $\mathrm{N}$ limitation, a process described as "N-mining" (Iversen et al., 2011). In the AspenFACE experiment in Wisconsin, USA, where trees were grown from the seedling stage to canopy closure, soil $\mathrm{N}$ turnover was accelerated by $\mathrm{CO}_{2}$ enrichment, with corresponding increases in both gross $\mathrm{N}$ mineralization and gross $\mathrm{N}$ immobilization (Holmes et al., 2006). In the Duke Forest experiment, where tree growth was enhanced over a longer time, Phillips et al. (2011) and Drake et al. (2011) reported an increased root exudation of $\mathrm{C}$ compounds accompanied by a stimulation of microbial activity. As a result, more $\mathrm{N}$ was mineralized under elevated $\mathrm{CO}_{2}$. In $\mathrm{N}$-fertilized sub-plots, however, these effects were not observed. In the Australian EucFACE experiment, the availability of $\mathrm{N}$ and $\mathrm{P}$ increased in the rhizosphere under the trees exposed to the $\mathrm{CO}_{2}$ enrichment. This finding was related to the degradation of organic matter as the activity of corresponding exoenzymes increased in the deeper soil (OchoaHueso et al., 2017). In our previous experiment in a mature mixed forest, we found that there was a higher availability of nitrate $\left(\mathrm{NO}_{3}{ }^{-}\right)$in the soil under broadleaved trees subjected to $\mathrm{CO}_{2}$ enrichment (Schleppi et al., 2012), with $\mathrm{N}$ isotope abundances indicating increased $\mathrm{N}$ mineralization and nitrification. Similar observations have been reported from subtropical (Langley et al., 2009) to treeline ecosystems (Hagedorn et al., 2008). All these reports can be interpreted as a priming effect, i.e., stimulation of SOM decomposition leading to a release of mineral nutrients (e.g., Kuzyakov, 2010).

Interactions between the nutrients and $\mathrm{C}$ cycles are complex, and the nutritional status of a forest appears to be crucial in determining its response to increased atmospheric $\mathrm{CO}_{2}$ concentrations. In the present study, we explored the effects of $\mathrm{CO}_{2}$ enrichment in the crown of mature Norway spruce trees within a mixed forest stand. Our goal was to assess how this enrichment affects the availability of nutrients in the soil under the treated trees in comparison with untreated trees in the same stand.

\section{MATERIALS AND METHODS}

\section{Site and Forest Type}

Our investigations were conducted as part of the Swiss Canopy Crane (SCC) project in Hofstetten, NW Switzerland $\left(47.47^{\circ} \mathrm{N}\right.$, $7.50^{\circ} \mathrm{E}, 550 \mathrm{~m}$ a.s.1.), in a mixed forest with dominating trees aged about 110 years and $\sim 35 \mathrm{~m}$ tall. Within the experimental area, the main tree species are Picea abies, Fagus sylvatica, Carpinus betulus, Quercus robur, and Q. petraea and Larix decidua, with some Acer campestre, Pinus silvestris, Tilia platiphyllos, and Abies alba. During the experiment, the stem basal area was ca. $40 \mathrm{~m}^{2}$ $\mathrm{ha}^{-1}$ and the leaf area index around 5. The soil is a shallow Rendzina on calcareous bedrock. It has a silty loam texture 
with a $\mathrm{pH}(\mathrm{KCl})$ of 5.6 in the upper $10 \mathrm{~cm}$ and 5.9 between 10 and $20 \mathrm{~cm}$ depth. These soil layers are largely decarbonated according to $\mathrm{HCl}$ tests. Meteorological data were taken from the MeteoSwiss station of Basel-Binningen, $10 \mathrm{~km}$ away, and adiabatically corrected for the difference in elevation. During the 5 years of the experiment, the average air temperature was $19.1^{\circ} \mathrm{C}$ during the warmest month (July) and $2.1^{\circ} \mathrm{C}$ during the coldest one (January), for an annual mean of $14.7^{\circ} \mathrm{C}$ and a growing season of 5.5 months (Asshoff et al., 2006). Annual precipitation was $910 \mathrm{~mm}$, of which $42 \%$ occurred during the winter halfyear. According to deposition maps (OFEV (Office fédéral de l'environnement), 2005), the annual input of $\mathrm{N}$ on the site is approximately $20 \mathrm{~kg} \mathrm{ha}^{-1}$, which is at the upper limit of the range of critical loads for this type of ecosystem.

\section{$\mathrm{CO}_{2}$ Treatment}

A FACE experiment was conducted from July 30, 2009 to October 30, 2014 using the same infrastructure as in our previous experiment with broadleaved trees (Schleppi et al., 2012). Ten Norway spruce trees were chosen within a distance of approximately $60 \mathrm{~m}$. On half of these trees, a fine web of perforated tubes was woven into the tree crowns using a $50 \mathrm{~m}$ construction crane. Pure $\mathrm{CO}_{2}$ was then pulse-released through these tubes (web-FACE technique, Pepin and Körner, 2002) to achieve a concentration of $550 \mathrm{mmol} \mathrm{mol}^{-1}$ in the crowns. Because the five $\mathrm{CO}_{2}$-enriched trees had to be within the reach of the crane and the control trees had to be further away to avoid contamination with extra $\mathrm{CO}_{2}$, this resulted in an imperfectly replicated design.

\section{Analysis of Soil Solution}

Two groups of two or three ceramic suction cups were installed at a depth of $12-15 \mathrm{~cm}$ under the crows of the studied trees, at an average distance of $3 \mathrm{~m}$ from the trunk. These suction cups were connected to a sampling bottle and further to one of four vacuum systems, each powered by a pump reaching a pressure of $\sim-400 \mathrm{hPa}$ below atmospheric pressure. Timers were used to activate the pumps for $15 \mathrm{~min}$ every $4 \mathrm{~h}$. All bottles were made of brown glass and were half dug into the soil to minimize algae development. As a protective measure against rodents, vacuum tubes were inserted into larger tubes reinforced with fiberglass. A soil solution sample from each tree was collected on average every 4 weeks, except when temperatures were below the freezing point in winter or when the soil was too dry, especially in the summer. This technique was previously shown to capture inorganic $\mathrm{C}$ depleted in ${ }^{13} \mathrm{C}$ under trees treated with ${ }^{13} \mathrm{C}$-depleted $\mathrm{CO}_{2}$ (Schleppi et al., 2012). This means that such suction cups effectively sample the soil solution as influenced by the activity of tree roots.

The obtained samples were immediately refrigerated, then filtered $(0.45 \mu \mathrm{m})$ and analyzed at the Swiss Federal Institute for Forest, Snow and Landscape Research (WSL, Birmensdorf). All analyses were conducted against international standards with methods accredited according to ISO 17025. Anion concentrations were measured using ion chromatography (IC). With this method, phosphate was almost always below the detection limit. Therefore, we also tested a pre-concentration by a factor of 10-20 with either lyophilization or ion-exchange resins. In the best case, however, only $30 \%$ of the samples had measurable concentrations and these analyses were thus not continued. Total dissolved N (TDN) was analyzed with a C and $\mathrm{N}$ analyzer. Ammonium concentrations, assessed with flow injection analysis (FIA) were below the detection limit most of the time, and this analysis was thus discontinued after 1 year. Dissolved reduced $\mathrm{N}(\mathrm{DRN})$ was calculated as TDN minus $\mathrm{NO}_{3}^{-}$$\mathrm{N}$. Because of the very low concentrations of $\mathrm{NH}_{4}^{+}-\mathrm{N}, \mathrm{DRN}$ is practically equivalent to dissolved organic $\mathrm{N}$ (DON).

\section{Ion-Exchange Resin Bags}

Resin bags were used to obtain integrative measurements of nutrient availability (Giblin et al., 1994; Schleppi et al., 2012). Cheesecloth bags $(1.5 \times 9 \mathrm{~cm}, 0.3 \mathrm{~mm}$ mesh size $)$ were filled with an ion-exchange resin mixture ( $5 \mathrm{~g}$ per bag). This mixture was half cation exchanger (Dowex HCR-W2 $\left(\mathrm{H}^{+}\right), 16-40$ mesh, from Sigma Aldrich, Buchs, Switzerland) and half anion exchanger (Dowex $1 \times 4\left(\mathrm{Cl}^{-}\right), 20-50$ mesh). Near each group of suction cups, three bags were buried in May 2014, $20-30 \mathrm{~cm}$ apart and at a depth of $10 \mathrm{~cm}$. The bags were removed after 6 months, brought to the laboratory and gently brushed under deionized water to remove soil particles. The three bags from each location were then extracted together by shaking them overnight in $200 \mathrm{ml} 1 \mathrm{M}$ $\mathrm{KCl}$. Ammonium in the extracts was analyzed by flow injection analysis (FIA). Because of the high chloride concentration, nitrate was measured by the ultraviolet absorption method of Norman and Stucki (1981), modified as described by Schleppi et al. (2012).

\section{Soil Analyses}

Three soil cores, $5 \mathrm{~cm}$ in diameter and $25 \mathrm{~cm}$ deep, were taken under each tree, also at an average distance of $3 \mathrm{~m}$ from the trunks. Sampling occurred in May 2014. The cores were separated into three layers at depths of 2 and $7 \mathrm{~cm}$ below the litter layer. The individual samples from each layer were bulked per tree, dried at $65^{\circ} \mathrm{C}$ and ground to powder. They were then acidified to remove inorganic C according to Walthert et al. (2010), then analyzed with a $\mathrm{C}$ and $\mathrm{N}$ elemental analyzer (EA3000, EuroVector, Milan, Italy) coupled to an isotope-ratio mass spectrometer (Delta V, Thermo Fisher, Bremen, Germany). Abundances of ${ }^{13} \mathrm{C}$ and ${ }^{15} \mathrm{~N}$ were expressed as $\delta$ values relative to Pee Dee Belemnite and to atmospheric $\mathrm{N}_{2}$, respectively.

\section{Net N Mineralization and Nitrification}

Net $\mathrm{N}$ mineralization and nitrification were assessed by the ${ }^{15} \mathrm{~N}$ dilution technique, adapted from Shrestha et al. (2014). Three soil cores per tree were taken in October 2014, close to the end of the experiment, using the same methods as described above. They were separated into two layers: $0-10$ and $10-20 \mathrm{~cm}$, then bulked per tree. Fresh samples were sieved to $2 \mathrm{~mm}$ and homogenized. Two sub-samples of $200 \mathrm{~g}$ each were labeled, one with ${ }^{15} \mathrm{NH}_{4} \mathrm{Cl}$ and the other with $\mathrm{K}^{15} \mathrm{NO}_{3}$ (both $99 \%{ }^{15} \mathrm{~N}$ abundance). This was done by dripping as homogenously as possible $1 \mathrm{~mL}$ of a $20 \mu \mathrm{mol} \mathrm{L}^{-1}$ solution over the sample with a pipette. After the labeled material was mixed thoroughly, it was partitioned into two $250 \mathrm{~mL}$ bottles. These bottles, each containing $100 \mathrm{~g}$ of soil, were incubated in the dark at $8^{\circ} \mathrm{C}$ for either 2 or $26 \mathrm{~h}$. After 
incubation, the soil samples were extracted by adding $150 \mathrm{~mL}$ $\mathrm{KCl} 1 \mathrm{M}$ to each bottle, then shaken at $1 \mathrm{~Hz}$ for $1.5 \mathrm{~h}$. For each original sample, a fifth $100 \mathrm{~g}$ sub-sample was extracted without prior labeling. The remaining fresh soil (50-150 g) was dried at $65^{\circ} \mathrm{C}$ to determine its water content.

After filtering all extracts on paper filters, their $\mathrm{NH}_{4}^{+}$and $\mathrm{NO}_{3}^{-}$concentrations were determined (after a $1 / 5$ dilution) by the same methods as described above for the extracts from the resin bags. ${ }^{15} \mathrm{~N}$ abundances in $\mathrm{NH}_{4}^{+}$and $\mathrm{NO}_{3}^{-}$were measured in the extracts according to Schleppi et al. (2006), using the measured concentrations of these ions to determine the volume to be used in order to have $\sim 50 \mu \mathrm{g} \mathrm{N}$ per sample.

\section{Needle Analyses}

Current-year twigs were collected from branches in the upper part of the crown of each tree near the end of the experiment, in September 2014 (using the crane for FACE trees and by tree climbers for the control trees). Needles were dried at $80^{\circ} \mathrm{C}$ and separated from the twigs. Between 300 and 500 needles were scanned by transparency at a resolution of 600 dpi using a flatbed scanner (Perfection V800, Epson, Nagano, Japan). After being ground to powder, the needles were analyzed for total $\mathrm{C}$ and $\mathrm{N}$ and for the respective heavier isotopes ${ }^{13} \mathrm{C}$ and ${ }^{15} \mathrm{~N}$ by combustion in an elemental analyzer and detection by mass spectrometry (same method as indicated above for soil samples). Other elements (S, P, K, Ca, Mg, Al, B, Cu, Fe, Mn, Ni, Zn, and $\mathrm{Ba}$ ) were determined by microwave digestion with $5 \mathrm{M}$ nitric acid $\left(\mathrm{HNO}_{3}\right)$ and $0.5 \mathrm{M}$ fluoric acid (HF), followed by analysis with ICP-AES (Optima 3000, Perkin-Elmer, Waltham, MA, USA).

\section{Statistical Analyses}

Analyses of variance (ANOVA) were performed to assess effects of the $\mathrm{CO}_{2}$ enrichment. Each tree was considered an experimental unit and each pair of a treated tree and the closest control tree was considered a block. Data were log-transformed where necessary, enabling us to use parametrical methods that require a normal distribution of the residuals. When statistics were performed on logarithms, averages and standard errors were back calculated into the original scale, thus giving geometric averages and geometric standard errors. For the results from the soil solution, we used repeated-measure (RM) ANOVA and distinguished between 3 periods: 2 samplings that started before the $\mathrm{CO}_{2}$ enrichment was turned on, 37 samplings that took place during the enrichment and nine samplings carried out after the end of the enrichment. The data obtained for this study are published in the EnviDat repository (Schleppi et al., 2019).

\section{RESULTS}

\section{Bulk Soil Analyses}

In the samples taken in September 2014, the organic C content of the soil was slightly higher under the $\mathrm{CO}_{2}$-enriched trees ( $p=0.005$, Table 1$)$. The ${ }^{13} \mathrm{C}$ abundance was slightly lower $(p$ $=0.016)$. The total $\mathrm{N}$ concentration was significantly higher in cores collected under $\mathrm{CO}_{2}$-enriched trees $(p=0.0002)$ and the ${ }^{15} \mathrm{~N}$ abundance was significantly higher $(p=0.003)$. The $\mathrm{C} / \mathrm{N}$ ratio, however, was not affected by the $\mathrm{CO}_{2}$ enrichment $(p=0.27)$. No significant interactions were observed between these parameters and the considered soil layers. A strong negative correlation was found between $\delta^{15} \mathrm{~N}$ and the $\mathrm{C} / \mathrm{N}$ ratio $(r=-0.87, p=0.0004)$.

\section{$\mathbf{N}$ in the Soil Solution}

In soil water obtained by the suction cups, $\mathrm{NO}_{3}^{-}$concentrations varied between the detection limit of $0.008 \mathrm{mg} \mathrm{N} \mathrm{L}^{-1}$ and a maximum of $37 \mathrm{mg} \mathrm{N} \mathrm{L}^{-1}$. Out of 550 samples, a total of 20 , or $3.6 \%$, were below the detection limit. In these cases, a value of half the detection limit was used for the statistical analyses, which were all based on logarithms in order to get residuals that were approximately normally distributed. A seasonality was detected in the $\mathrm{NO}_{3}^{-}$concentrations, with a peak at the end of March and a minimum at the end of September, with an amplitude of \pm 0.36 in base-10 logarithmic scale. Considering this seasonality as an harmonic curve in mixed linear models did not affect the statistical tests and is thus not further considered hereafter. During the whole treatment period from July 30, 2009 to October 30, 2014, the $\mathrm{NO}_{3}^{-}-\mathrm{N}$ concentrations under the $\mathrm{CO}_{2}$ enriched trees were one order of magnitude higher (average $\left.2.74 \mathrm{mg} \mathrm{L}^{-1}\right)$ than those under the control trees $\left(0.25 \mathrm{mg} \mathrm{L}^{-1}\right.$; Figure 1). Because of the high variability between the locations (overall geometric standard error 2.07), this large difference was statistically only marginally significant (RMANOVA: $p=0.051$ ). Comparing these 37 sampling periods with the two before or during the very start of the treatment resulted in a significant interaction ( $p=0.0041$ ), showing that the difference during the $\mathrm{CO}_{2}$ enrichment was larger than before its start. On the contrary, there was no significant interaction $(p=0.43)$ when the nine sampling periods after the end of the $\mathrm{CO}_{2}$ enrichment were compared with those during the enrichment. Within treatments, $\mathrm{NO}_{3}^{-}$concentrations were not significantly correlated with the total $\mathrm{N}$ concentration of the soil (control: $r=-0.23, \mathrm{CO}_{2}$ enrichment: $r=0.26$ ).

Because dissolved reduced $\mathrm{N}$ (DRN) is calculated as the difference between TDN and $\mathrm{NO}_{3}^{-}-\mathrm{N}$, the obtained numbers were highly variable (geometric standard error 3.3). In the control samples (average $0.18 \mathrm{mg} \mathrm{L}^{-1}$ ), the concentrations were nevertheless significantly higher $(p=0.025)$ than under the $\mathrm{CO}_{2}$ enriched trees $\left(0.02 \mathrm{mg} \mathrm{L}^{-1}\right)$. When tested as a covariate, the water volume collected per suction cup did not appear to play a significant role $\left(p=0.56\right.$ for $\mathrm{NO}_{3}^{-}-\mathrm{N}, p=0.44$ for $\left.\mathrm{DRN}\right)$.

\section{Other Elements in the Soil Solution}

The concentrations of $\mathrm{SO}_{4}^{2-}$ were significantly higher under the $\mathrm{CO}_{2}$-enriched trees than under the control trees $(5.6 \mathrm{vs} .4 .3 \mathrm{mg}$ $\left.\mathrm{L}^{-1}, p=0.045\right)$. However, this situation appeared to prevail already before the experiment as the interaction with the time period was not significant $(p=0.85)$.

$\mathrm{Mg}^{2+}$ concentrations were also higher in the $\mathrm{CO}_{2}$ treatment (1.04 vs. $0.64 \mathrm{mg} \mathrm{L}^{-1}, p=0.012$ ), and here there was a tendency toward a positive interaction in favor of the $\mathrm{CO}_{2}$ enrichment $(p=0.089)$. Other parameters of the soil solution were not significantly affected by the $\mathrm{CO}_{2}$ treatment: $\mathrm{pH}$ (average 7.45), $\mathrm{Ca}^{2+}\left(29 \mathrm{mg} \mathrm{L}^{-1}\right), \mathrm{K}^{+}\left(0.80 \mathrm{mg} \mathrm{L}^{-1}\right), \mathrm{Cl}^{-}\left(2.7 \mathrm{mg} \mathrm{L}^{-1}\right)$, inorganic $\mathrm{C}\left(13 \mathrm{mg} \mathrm{L}^{-1}\right)$, and dissolved organic $\mathrm{C}\left(7.7 \mathrm{mg} \mathrm{L}^{-1}\right)$. 
TABLE 1 | Results of bulk soil analyses of soil cores taken near the end of the $\mathrm{CO}_{2}$ enrichment.

\begin{tabular}{|c|c|c|c|c|c|c|}
\hline Treatment & Soil layer $(\mathbf{c m})$ & $\mathrm{C}\left(\mathrm{g} \mathrm{kg}^{-1}\right)$ & $\delta^{13} \mathrm{C}(\%)$ & $\mathbf{N}\left(\mathbf{g ~ k g}^{-1}\right)$ & $\delta^{15} \mathrm{~N}(\%)$ & $\mathrm{C} / \mathrm{N}$ \\
\hline \multirow[t]{2}{*}{ Ambient $\mathrm{CO}_{2}$} & $0-10$ & 37.5 & -26.9 & 2.88 & 1.23 & 13.0 \\
\hline & $10-20$ & 20.9 & -26.1 & 1.92 & 3.37 & 11.0 \\
\hline & $10-20$ & 24.6 & -26.4 & 2.26 & 3.60 & 11.0 \\
\hline Standard error & & 2.4 & 0.2 & 0.02 & 0.06 & 0.1 \\
\hline$p$ (treatment $\times$ layer) & & 0.80 & 0.61 & 0.62 & 0.07 & 0.32 \\
\hline
\end{tabular}

Mean values and standard errors (from ANOVA) are shown, along with p-values from statistical analyses.

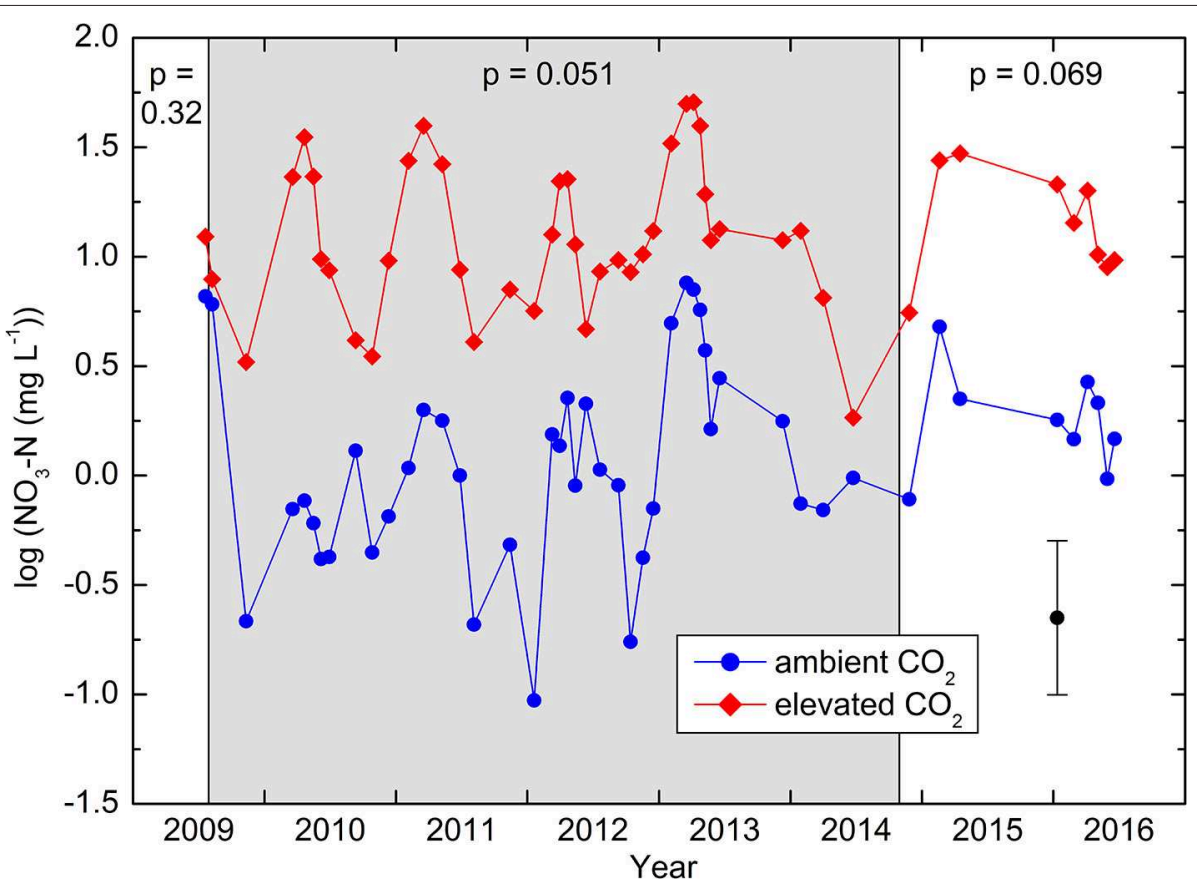

FIGURE 1 | Nitrate-N concentrations in the soil solution, expressed in logarithmic scale. Means of five replicates, each consisting of 4-5 suction cups each. The vertical bar represents \pm standard error. The period with $\mathrm{CO}_{2}$ enrichment is shaded in gray. $p$-values obtained by RMANOVA are indicated for each period. The differences during the enrichment are significantly larger than those before enrichment $(p=0.004)$.

\section{Ammonium and Nitrate in the Resin Bags}

The amounts of $\mathrm{NO}_{3}^{-}$extracted from the resin bags were less variable than the $\mathrm{NO}_{3}^{-}$concentrations in the soil solution, but a $\log$-transformation was appropriate in this case as well to improve the normality of the residuals. After 6 months of incubation in the soil, $1.12 \mathrm{mg} \mathrm{NO}_{3}^{-}-\mathrm{N}$ per bag was found on average under the $\mathrm{CO}_{2}$-enriched trees, roughly twice as much as under the control trees $(0.52 \mathrm{mg})$. The difference was significant $(p=0.022$, Figure $2 \mathrm{~A}) . \mathrm{NH}_{4}^{+}$also tended to increase $(p=0.054)$, with $0.48 \mathrm{mg} \mathrm{N}$ per bag in the $\mathrm{CO}_{2}$ treatment vs. $0.37 \mathrm{mg}$ in the control. There was a high correlation between both $\mathrm{N}$ forms $(r=0.89, p<0.0001)$. Measurements of ${ }^{15} \mathrm{~N}$ in the captured $\mathrm{NO}_{3}^{-}$and $\mathrm{NH}_{4}^{+}$did not show a significant effect of the $\mathrm{CO}_{2}$ enrichment on $\mathrm{N}$ isotope fractionation (Figure 2B). There was no significant correlation between $\mathrm{NO}_{3}^{-}$or $\mathrm{NH}_{4}^{+}$and the total $\mathrm{N}$ concentration in the soil, neither per treatment nor overall. There was a significant negative correlation between $\delta^{15} \mathrm{~N}$ in the bulk soil and $\delta^{15} \mathrm{~N}_{\text {in }} \mathrm{NO}_{3}^{-}$from the resins bags when all 10 trees were considered together $(r=-0.64, p=0.045)$.

\section{Soil Extracts, Gross N Mineralization, and Gross Nitrification}

The soil samples used for extraction and for the ${ }^{15} \mathrm{~N}$ dilution assays contained $28 \%$ of water relative to their dry mass. All data obtained from these measurement were logtransformed prior to statistical analyses in order to improve the normality of the residuals. $\mathrm{KCl}(1 \mathrm{M})$ extracts showed an increase in $\mathrm{NO}_{3}^{-}$concentration under the $\mathrm{CO}_{2}$-enriched trees compared to the control trees (Figure 3). Considering the soils layers separately, the increase was significant only in the 
TABLE 2 | Traits and nutrient concentrations of current-year needles taken from the upper part of tree crowns near the end of the FACE experiment.

\begin{tabular}{|c|c|c|c|c|c|}
\hline Parameter & Ambient $\mathrm{CO}_{2}$ & Elevated $\mathrm{CO}_{2}$ & Standard error & $p$-value & Interpretation \\
\hline Needle dry matter (mg) & 3.92 & 4.78 & 0.42 & 0.068 & \\
\hline Needle area $\left(\mathrm{mm}^{2}\right)$ & 21.3 & 21.6 & 1.4 & 0.90 & \\
\hline$\delta^{13} \mathrm{C}(\%)$ & -27.66 & -31.24 & 0.65 & 0.003 & \\
\hline$\delta^{15} \mathrm{~N}(\%)$ & -2.69 & -1.91 & 0.30 & 0.11 & \\
\hline $\mathrm{Cu}\left(\mu \mathrm{g} \mathrm{g}^{-1}\right)$ & 4.54 & 5.70 & 0.79 & 0.43 & \\
\hline $\mathrm{Fe}\left(\mu \mathrm{g} \mathrm{g}^{-1}\right)$ & 47.2 & 39.5 & 6.3 & 0.30 & \\
\hline $\mathrm{K}\left(\mu \mathrm{g} \mathrm{g}^{-1}\right)$ & 7180 & 7170 & 660 & 0.99 & Normal \\
\hline$M g\left(\mu g^{-1}\right)$ & 814 & 762 & 80 & 0.62 & Low normal $\rightarrow$ latent deficient \\
\hline $\operatorname{Mn}\left(\mu g^{-1}\right)$ & 235 & 271 & 50 & 0.62 & \\
\hline $\mathrm{N} / \mathrm{P}$ & 10.9 & 12.7 & 1.4 & 0.40 & Within $\rightarrow$ above range \\
\hline $\mathrm{N} / \mathrm{K}$ & 2.17 & 2.52 & 0.27 & 0.36 & Within range \\
\hline $\mathrm{N} / \mathrm{Ca}$ & 1.67 & 1.97 & 0.22 & 0.38 & Below range \\
\hline $\mathrm{N} / \mathrm{Mg}$ & 18.4 & 24.8 & 2.5 & 0.13 & Within $\rightarrow$ above range \\
\hline
\end{tabular}

The interpretation in the last column is after Mellert and Göttlein (2012).

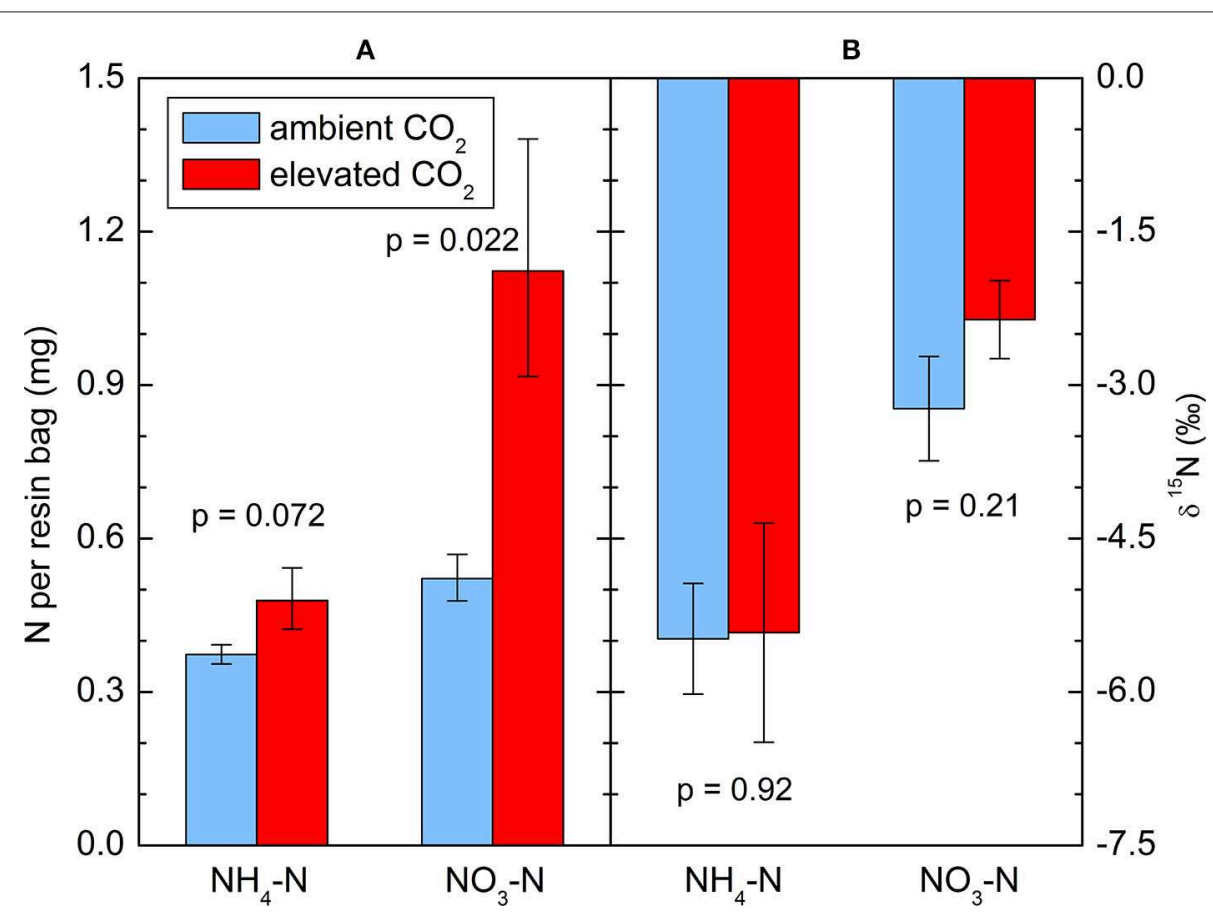

FIGURE 2 | (A) $\mathrm{NH}_{4}^{+}$and $\mathrm{NO}_{3}^{-}$captured in resin bags during the 2014 growing season, and (B) the ${ }^{15} \mathrm{~N}$ abundance of these ions. Means \pm standard errors of five replicates, each consisting of 6 bags: (A) geometric, (B) arithmetic. $p$-values indicate the effect of $\mathrm{CO}_{2}$ treatment.

layer $10-20 \mathrm{~cm}$. Neither the effect of the soil layer nor the interaction between layer and $\mathrm{CO}_{2}$ treatment were significant, but there was a positive correlation between $\mathrm{NO}_{3}^{-}$and total $\mathrm{N}$ concentration in the soil, which was significant when all 10 trees were taken together $(r=0.68, p=0.030)$. More
$\mathrm{NH}_{4}^{+}$was extracted from the top $10 \mathrm{~cm}$ than from the deeper layer $(10-20 \mathrm{~cm})$ but no effect of the $\mathrm{CO}_{2}$ enrichment was detected $(p=0.42)$.

Neither the gross $\mathrm{N}$ mineralization rate $(p=0.71)$ nor the gross nitrification rate $(p=0.51)$ were affected 


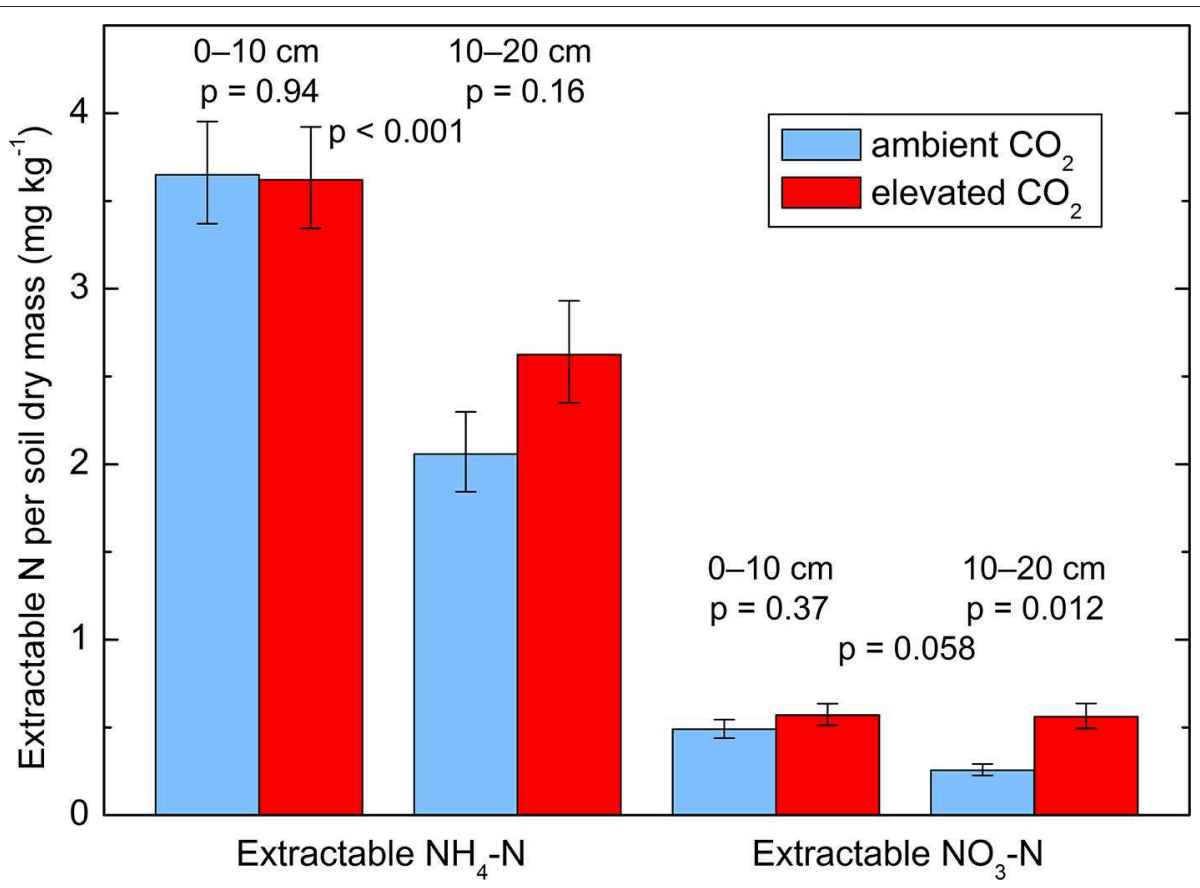

FIGURE 3 | Extractable $\mathrm{NH}_{4}^{+}$and $\mathrm{NO}_{3}^{-}$in two soil layers (0-10 and 10-20 cm depth) from soil cores taken in October 2014. Geometric means \pm geometric standard errors of five replicates, each consisting of three cores. $p$-values indicate the effect of $\mathrm{CO}_{2}$ treatment and of soil layer. Interactions between treatment and layer are not significant.

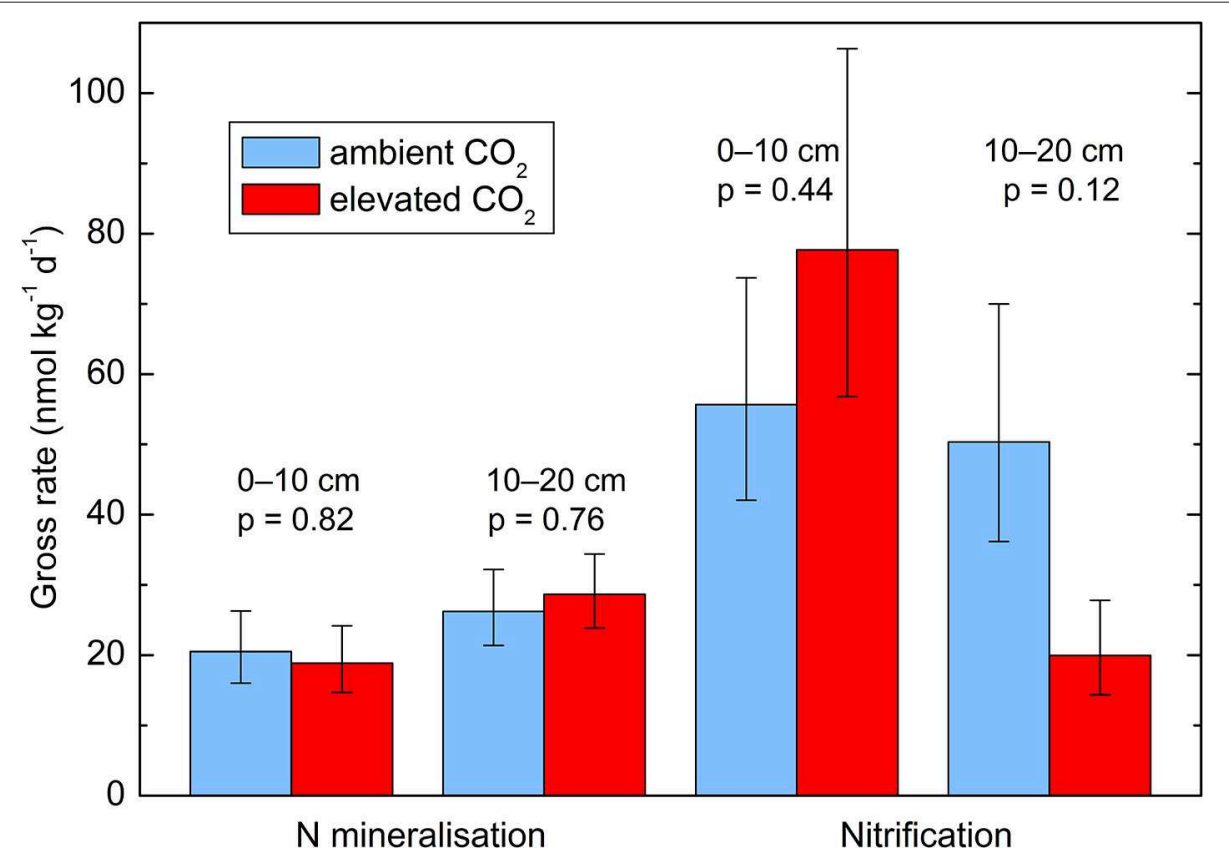

FIGURE 4 | Gross N transformation rates in two soil layers (0-10 and 10-20 cm depth) from soil cores taken in October 2014. Geometric means \pm geometric standard errors of five replicates, each consisting of three cores. $p$-values are indicate the effect of $\mathrm{CO}_{2}$ treatment. The effects of soil layer and the interactions between treatment and layer are not significant.

by the $\mathrm{CO}_{2}$ enrichment in the incubated soil samples (Figure 4). There was no significant effect of soil depth and no interactions between layer and $\mathrm{CO}_{2}$ treatment. There were further only non-significant negative correlations between $\mathrm{N}$ transformation rates and the total $\mathrm{N}$ concentration in the soil. 


\section{Foliar Traits and Nutrients}

The average length and area of the needles was not affected by the $\mathrm{CO}_{2}$ enrichment in the tree crowns, but the dry mass per needle tended to increase $(p=0.068)$, as well as the dry mass per area $(p=0.079$, Table 2$)$. The $\delta^{13} \mathrm{C}$ signal became clearly more negative $(p=0.0034)$ as a result of exposure to isotopically depleted $\mathrm{CO}_{2}$ enrichment gas, and $\delta^{15} \mathrm{~N}$ tended to increase $(p$ $=0.061$ ). According to the thresholds of Mellert and Göttlein (2012), the K nutrition of the trees was normal, while P showed a latent deficiency. $\mathrm{Mg}$ was also partly in latent deficiency, whereas $\mathrm{Ca}$ showed an extreme surplus. $\mathrm{N}$ was between a low-normal range and a surplus. As the only plant nutrient, $\mathrm{N}$ tended to be higher in the needles of $\mathrm{CO}_{2}$-enriched trees $(p=0.055)$.

\section{DISCUSSION}

Our experiment showed an increased $\mathrm{N}$ availability under trees subjected to elevated $\mathrm{CO}_{2}$ concentrations. Because gross $\mathrm{N}$ mineralization and nitrification were not affected, other mechanisms, but also some possible artifacts have to be taken into account. After 5.5 years of treatment, the organic $\mathrm{C}$ and $\mathrm{N}$ content of the soil under the $\mathrm{CO}_{2}$-enriched trees was slightly but significantly higher than under control trees. Our experiment could not be set up in a true block design because all FACE trees had to be within reach of the crane and not too close to control trees to avoid contamination. Considering the low turnover of soil organic matter (SOM), the increase in soil organic $\mathrm{C}$ and $\mathrm{N}$ was probably not an effect of the treatment but a prevailing difference linked to the imperfect statistical design. The studied spruce trees were in a mixed stand, so some heterogeneity in SOM content was expected, both from the intermingling of the root systems and from wind-driven litterfall. The similarity of the $\mathrm{C} / \mathrm{N}$ ratio between the soil under the control and the $\mathrm{CO}_{2}$-enriched trees is, however, a sign that the quality of the SOM did not differ much. The total soil $\mathrm{N}$ concentration correlated only with extractable $\mathrm{NO}_{3}^{-}$, which was measured from the same soil cores. This means that their correlation includes the soil variability at the centimeter scale. At the level of the experimental unit (i.e., individual tree), no other measured parameter of the $\mathrm{N}$ cycle correlated with total $\mathrm{N}$. The negative correlation observed between $\delta^{15} \mathrm{~N}$ in the bulk soil and $\delta^{15} \mathrm{~N}$ in $\mathrm{NO}_{3}^{-}$from the resins bags shows that $\mathrm{NO}_{3}^{-}$is not directly derived from the mineralization of an homogenous organic pool; this means that the short-term $\mathrm{N}$ dynamics are not directly related to total soil N. Overall, these findings indicate that prevailing differences in total $\mathrm{N}$ (which is mainly organic N) did not interfere with our measurements and their interpretation.

In our previous study on the same site but with broadleaved trees (Schleppi et al., 2012), we found that $\mathrm{CO}_{2}$ enrichment (FACE) in the tree crowns led to an increased availability of $\mathrm{NO}_{3}^{-}$in the soil. This same finding was reached in the present experiment. The time lag between the two experiments was short and did not allow a longer period of soil solution sampling before the new treatment started. Nevertheless, the observed increase in $\mathrm{NO}_{3}^{-}$during the years of $\mathrm{CO}_{2}$ enrichment was large and significant when compared to the short pre-treatment period. This was confirmed both by $\mathrm{NO}_{3}^{-}$captured by ion-exchange resin bags and by the direct extraction from soil cores. One of the hypotheses derived from the study with broadleaved trees was that trees may need to take up less $\mathrm{N}$ to maintain their photosynthesis when exposed to higher $\mathrm{CO}_{2}$ concentrations, thus leaving more available $\mathrm{N}$ in the soil. This hypothesis would fit with the observed seasonality of $\mathrm{NO}_{3}^{-}$in the soil solution, which was very similar in the two experiments with a peak in the spring. This could indicate that $\mathrm{NO}_{3}^{-}$concentrations are controlled more by the demand of the plants than by production in the soil. Decreasing concentrations during the growing season indeed indicate (independently of the $\mathrm{CO}_{2}$ treatment) that $\mathrm{N}$ uptake by trees dominates during this period of the year when both mineralization and uptake are maximal. However, in the present experiment, tree needles contained more $\mathrm{N}$ when exposed to the $\mathrm{CO}_{2}$ enrichment, which contradicts the hypothesis of a reduced uptake. On the contrary, our results indicate that the higher availability of nitrate in the soil triggered increased uptake by the spruce trees.

Another hypothesis derived from our previous study was that the greater $\mathrm{N}$ availability was related to more sustained soil biological activity during dry periods under $\mathrm{CO}_{2}$-enriched trees. Water saving had indeed been shown for these broadleaved trees, because they tended to reduce stomatal conductance under higher atmospheric $\mathrm{CO}_{2}$ concentrations (Bader et al., 2009). In the present study, however, stomatal conductance of the spruce trees was not affected by elevated $\mathrm{CO}_{2}$ and photosynthetic capacity showed little downward adjustment (Leuzinger and Bader, 2012; Klein et al., 2016a). This finding is in line with a general divergence between broadleaved trees and conifers, with the latter tending to maintain stomatal conductance under elevated $\mathrm{CO}_{2}$ (Klein and Ramon, 2019). It may also be related to the aforementioned tendency of the conifers needles to maintain or even increase their $\mathrm{N}$ concentration under elevated $\mathrm{CO}_{2}$. We can thus reject the hypothesis that $\mathrm{CO}_{2}$ enrichment affects soil $\mathrm{N}$ availability via reduced stomatal conductance and higher soil moisture, at least in the case of our spruce trees and probably more generally for conifers.

The most likely explanation for the increased $\mathrm{NO}_{3}^{-}$ concentrations observed under the $\mathrm{CO}_{2}$-enriched trees in our study is a stimulation of SOM decomposition. Elevated $\mathrm{CO}_{2}$ increases the rhizodeposition of plants in general (Nie et al., 2013). In the present experiment, Klein et al. (2016a) found sustained higher photosynthetic rates in the $\mathrm{CO}_{2}$ enriched trees, but no corresponding increase in growth or daytime respiration (neither above nor below ground). This, along with evidence for a significant $\mathrm{C}$ transfer from $\mathrm{CO}_{2}$-enriched spruce trees to unenriched neighbor trees (Klein et al., 2016b), suggests a larger transfer of $\mathrm{C}$ to ectomycorrhizae and to the rhizosphere under elevated $\mathrm{CO}_{2}$. The importance of such inputs for the mineral nutrition of $\mathrm{CO}_{2}$-enriched trees is now widely recognized (Holmes et al., 2006; Iversen et al., 2011; Phillips et al., 2011; Schleppi et al., 2012; Meier et al., 2017; Ochoa-Hueso et al., 2017). Considering these studies, the 
key process appears to be a priming effect, although it is not clear how much of it is due to the release of root exudates to the rhizosphere and how much is mediated by mycorrhizae. Mycorrhizae are indeed able to transfer $\mathrm{C}$ compounds to microbes even beyond the rhizosphere (Klein et al., 2016b; Gorka et al., 2019). An increased production of exoenzymes has been found in several studies with $\mathrm{CO}_{2}$ enrichment, and this effect has depended on the availability of $\mathrm{N}$ in the soil (Drake et al., 2013; Meier et al., 2017; Ochoa-Hueso et al., 2017).

For a sustained effect on $\mathrm{N}$ availability, as observed also in our experiments, one would expect that priming affects recalcitrant, $\mathrm{N}$-containing SOM. Increased activities have been reported mainly for exoenzymes decomposing starch and cellulose, but the abovementioned studies used either short-term artificial enrichment of the soil with exudates (Drake et al., 2013; Meier et al., 2017; Stringlis et al., 2018) or a $\mathrm{CO}_{2}$ enrichment lasting only 17 months (Ochoa-Hueso et al., 2017). Longerterm priming effects may additionally involve more recalcitrant SOM decomposed mainly by K-strategy microbes (Chen et al., 2014), which would fit with the fact that $\mathrm{CO}_{2}$-induced increases in $\mathrm{N}$ (and P) availability have been reported mainly in deeper soil layers (Iversen et al., 2011; Ochoa-Hueso et al., 2017). Our study was not conceived to unravel details of these mechanisms, but we were able to show an enhanced availability of $\mathrm{NO}_{3}^{-}$ without a concomitant increase in soil $\mathrm{N}$ mineralization and nitrification, which is an indication of the importance of the roots and mycorrhizae. Mineralization and nitrification were indeed measured in the laboratory, between the second and third day after soil coring. This means that fine roots were no longer supplied with $\mathrm{C}$ compounds and their exudation activity was then already much lower than in situ, or even nil. In a meta-analysis including mainly non-nutrient-limited crops and trees, Van Groenigen et al. (2017) found that SOM decomposition is not significantly affected by $\mathrm{CO}_{2}$ enrichment. This, however, does not exclude that priming fueled by root exudates takes place, especially in nutrient-limited systems. The fact that ${ }^{15} \mathrm{~N}$ tended to increase in the needles of our $\mathrm{CO}_{2}$ enriched trees but not in the bulk soil is an indication of the specificity of rhizosphere processes. The same kind of spatial difference between bulk soil and the rhizosphere may also explain why a temperature-induced increase in decomposition can result in higher DON concentrations (Dawes et al., 2017) while the contrary was observed in our study, where carbonrich root exudates probably promote also the mineralization of DON.

Considering the quick response of soil solution $\mathrm{NO}_{3}^{-}$after starting the $\mathrm{CO}_{2}$ enrichment, one might have expected a rapid return to concentrations close to the control level after the treatment was terminated. This was not the case, and two factors could explain why $\mathrm{NO}_{3}^{-}$concentrations remained elevated for two more years. First, the starch content in the stems of the $\mathrm{CO}_{2}$-enriched trees was slightly increased (Klein et al., 2016a), and an accumulation in coarse roots probably also took place. These reserves may be used over at least a year to sustain the production of exudates by fine roots. Second, if we postulate a priming effect, then it is to some extent a self-perpetuating process, with microbial nutrients fostering the release of microbial nutrients.

Phosphate or total P in the soil solution could not be measured in the present study because concentrations were below the detection limit. However, $\mathrm{P}$ concentrations measured in the foliage were almost the same in the control trees and $\mathrm{CO}_{2}$ enriched trees. The trees were thus apparently able to maintain their foliar $\mathrm{P}$ concentration even though their needles were slightly heavier under higher $\mathrm{CO}_{2}$ concentrations. Nevertheless, the higher foliar N/P ratio points toward increasing $\mathrm{P}$ limitation. A trend in the same direction is observed over time at Swiss forest sites and more generally for European forests (Braun et al., 2010; Jonard et al., 2015). Increasing $\mathrm{CO}_{2}$ concentrations may thus add to the imbalance between $\mathrm{P}$ and $\mathrm{N}$ caused by decades of atmospheric $\mathrm{N}$ deposition. Such an imbalance may even partly explain the $\mathrm{C}$ that was missing in the budget established for our experiment by Klein et al. (2016a). Indeed, $P$ limitation decreases the efficiency of plant respiration (Jiang et al., 2019), and night respiration (that was not included in our $\mathrm{C}$ budget) may increase along the $\mathrm{N} / \mathrm{P}$ ratio. Beside $\mathrm{P}, \mathrm{Mg}$ nutrition is also a matter of concern because the $\mathrm{N} / \mathrm{Mg}$ ratio was significantly higher in $\mathrm{CO}_{2}$-enriched trees, reaching values above the normal range. The very high foliar concentrations of $\mathrm{Ca}$, on the other hand, can be interpreted as resulting from the high $\mathrm{Ca}$ content of the soil and its parent material (Rendzina on relatively $\mathrm{Mg}$-poor limestone). As transpiration was not found to respond to elevated $\mathrm{CO}_{2}$ in these trees (Leuzinger and Bader, 2012), transport by sap flow can be assumed to be similar across treatments. Beside physiological effects, the differences between $\mathrm{Mg}$ and $\mathrm{Ca}$ underline the importance of the parent material for the nutrition with divalent cations. Increasing atmospheric $\mathrm{CO}_{2}$ concentrations therefore have the potential to worsen the $\mathrm{Mg}$ nutrition especially in forests growing on soils that are more acidic than that of our experiment.

In conclusion, our results suggest a release of soil $\mathrm{N}$ by $\mathrm{CO}_{2-}$ driven priming, which is not paralleled by an increasing $\mathrm{P}$ and $\mathrm{Mg}$ availability. Both the duration of the priming effect and the speed at which $\mathrm{N}$ deposition will be reduced in the future are unknown. It is therefore difficult to predict how fast and how far an imbalance between $\mathrm{N}, \mathrm{P}$, and $\mathrm{Mg}$ will develop and constrain tree growth under the increasing atmospheric $\mathrm{CO}_{2}$ concentrations of the future.

\section{DATA AVAILABILITY STATEMENT}

Supporting data are available on the EnviDat repository, doi: 10.16904/envidat.74.

\section{AUTHOR CONTRIBUTIONS}

CK conceived and supervised the FACE experiment, and obtained most of the funding. TK ran the experiment and supervised the work done above ground. PS planned, set up and ran measurements in, and samplings from 
the soil and wrote the manuscript with the help of the co-authors.

\section{FUNDING}

The Hofstetten FACE experiment was supported by the Swiss National Science Foundation project FORCARB (31003A_14753/1) allocated to CK. The crane was sponsored by the Swiss Federal Office of the Environment (FOEN). TK was

\section{REFERENCES}

Asshoff, R., Zotz, G., and Körner, C. (2006). Growth and phenology of mature temperate forest trees in elevated $\mathrm{CO}_{2}$. Glob. Change Biol. 12, 848-861. doi: 10.1111/j.1365-2486.2006.01133.x

Bader, M., Hiltbrunner, E., and Körner, C. (2009). Fine root responses of mature deciduous forest trees to free air carbon dioxide enrichment (FACE). Func. Ecol. 23, 913-921. doi: 10.1111/j.1365-2435.2009.01574.x

Bader, M. K.-F., Siegwolf, R., and Körner, C. (2010). Sustained enhancement of photosynthesis in mature deciduous forest trees after 8 years of free air $\mathrm{CO}_{2}$ enrichment. Planta 232, 1115-1125. doi: 10.1007/s00425-010-1240-8

Braun, S., Thomas, V. F. D., Quiring, R., and Flückiger, W. (2010). Does nitrogen deposition increase forest production? The role of phosphorus. Environ. Pollut. 158, 2043-2052. doi: 10.1016/j.envpol.2009.11.030

Chen, R., Senbayram, M., Blagodatsky, S., Myachina, O., Dittert, K., Lin, X., et al. (2014). Soil $\mathrm{C}$ and $\mathrm{N}$ availability determine the priming effect: microbial $\mathrm{N}$ mining and stoichiometric decomposition theories. Glob. Change Biol. 20, 2356-2367. doi: 10.1111/gcb.12475

Dawes, M. A., Schleppi, P., Hättenschwiler, S., Rixen, C., and Hagedorn, F. (2017). Soil warming opens the nitrogen cycle at the alpine treeline. Glob. Change Biol. 23, 421-434. doi: 10.1111/gcb.13365

Drake, J. E., Darby, D. A., Giasson, M.-A., Kramer, M. A., Phillips, R. P., and Finzi, A. C. (2013). Stoichiometry constrains microbial response to root exudation-insights from a model and a field experiment in a temperate forest. Biogeosciences 10, 821-838. doi: 10.5194/bg-10-821-2013

Drake, J. E., Gallet-Budynek, A., Hofmockel, K. S., Bernhardt, E. S., Billings, S. A., Jackson, R. B., et al. (2011). Increases in the flux of carbon belowground stimulate nitrogen uptake and sustain the long-term enhancement of forest productivity under elevated $\mathrm{CO}_{2}$. Ecol. Lett. 14, 349-357. doi: 10.1111/j.1461-0248.2011.01593.x

Ellsworth, D. S., Anderson, I. C., Crous, K. Y., Cooke, J., Drake, J. E., Gherlenda, A. N., et al. (2017). Elevated $\mathrm{CO}_{2}$ does not increase eucalypt forest productivity on a low-phosphorus soil. Nat. Climate Change 7, 279-283. doi: $10.1038 /$ nclimate 3235

Giblin, A. E., Laundre, J. A., Nadelhoffer, K. J., and Shaver, G. R. (1994). Measuring nutrient availability in arctic soils using ion exchange resins: a field test. Soil Sci. Soc. Am. J. 58, 1154-1162. doi: 10.2136/sssaj1994.036159950058000 $40021 x$

Gorka, S., Dietrich, M., Mayerhofer, W., Gabriel, R., Wiesenbauer, J., Martin, V., et al. (2019). Rapid transfer of plant photosynthates to soil bacteria via ectomycorrhizal hyphae and its interaction with nitrogen availability. Front. Microbiol. 10:168. doi: 10.3389/fmicb.2019.00168

Hagedorn, F., van Hees, P. A. W., Handa, I. T., and Hättenschwiler, S. (2008). Elevated atmospheric $\mathrm{CO}_{2}$ fuels leaching of old dissolved organic matter at the alpine treeline. Glob. Biogeochem. Cycles 22:GB2004. doi: 10.1029/2007GB003026

Holmes, W. E., Zak, D. R., Pregitzer, K. S., and King, J. S. (2006). Elevated $\mathrm{CO}_{2}$ and $\mathrm{O}_{3}$ alter soil nitrogen transformations beneath trembling aspen, paper birch, and sugar maple. Ecosystems 9, 1354-1363. doi: 10.1007/s10021-006-0163-5

Inauen, N., Körner, C., and Hiltbrunner, E. (2012). No growth stimulation by $\mathrm{CO}_{2}$ enrichment in alpine glacier forefield plants. Glob. Change Biol. 18, 985-999. doi: 10.1111/j.1365-2486.2011.02584.x

Iversen, C. M., Hooker, T. D., Classen, A. T., and Norby, R. J. (2011). Net mineralization of $\mathrm{N}$ at deeper soil depths as a potential mechanism for sustained co-funded by the Plant Fellows program of the Zürich-Basel Plant Science Center (PSC) through the EU FP7 Marie Curie action.

\section{ACKNOWLEDGMENTS}

We thank D. Pezzotta and his team from theWSL central lab for chemical analyses and Dr. M. Dawes for language editing of the manuscript. forest production under elevated $\left[\mathrm{CO}_{2}\right]$. Glob. Change Biol. 17, 1130-1139. doi: 10.1111/j.1365-2486.2010.02240.x

Iversen, C. M., and Norby, R. J. (2008). Nitrogen limitation in a sweetgum plantation: implications for carbon allocation and storage. Canad. J. Forest. Res. 38, 1021-1032. doi: 10.1139/X07-213

Jiang, M., Caldararu, S., Zaehle, S., Ellsworth, D. S., and Medlyn, B. E. (2019). Towards a more physiological representation of vegetation phosphorus processes in land surface models. New Phytol. 222, 1223-1229. doi: $10.1111 / \mathrm{nph} .15688$

Johnson, D. W. (2006). Progressive $\mathrm{N}$ limitation in forests: review and implications for long-term responses to elevated $\mathrm{CO}_{2}$. Ecology 87, 64-75. doi: 10.1890/04-1781

Jonard, M., Fürst, A., Verstraeten, A., Thimonier, A., Timmermann, V., Potočić N., et al. (2015). Tree mineral nutrition is deteriorating in Europe. Glob. Change Biol. 21, 418-430. doi: 10.1111/gcb.12657

Klein, T., Bader, M. K.-F., Leuzinger, S., Mildner, M., Schleppi, P., Siegwolf, R. T. W., et al. (2016a). Growth and carbon relations of mature Picea abies trees under five years of free air $\mathrm{CO}_{2}$ enrichment. J. Ecol. 104, 1720-1733. doi: $10.1111 / 1365-2745.12621$

Klein, T., and Ramon, U. (2019). Stomatal sensitivity to $\mathrm{CO}_{2}$ diverges between angiosperm and gymnosperm tree species. Func. Ecol. 33, 1411-1424. doi: $10.1111 / 1365-2435.13379$

Klein, T., Siegwolf, R. T. W., and Körner, C. (2016b). Belowground carbon trade among tall trees in a temperate forest. Science 352, 342-344. doi: $10.1126 /$ science.aad6188

Körner, C. (2006). Plant $\mathrm{CO}_{2}$ responses: an issue of definition, time and resource supply. New Phytol. 172, 393-411. doi: 10.1111/j.1469-8137.2006.01886.x

Körner, C. (2017). A matter of tree longevity. Science 355, 130-131. doi: $10.1126 /$ science.aal2449

Kuzyakov, Y. (2010). Priming effects: interactions between living and dead organic matter. Soil Biol. Biochem. 42, 1363-1371. doi: 10.1016/j.soilbio.2010.04.003

Langley, J. A., McKinley, D. C., Wolf, A. A., Hungate, B. A., Drake, B. G., and Megonigal, J. P. (2009). Priming depletes soil carbon and releases nitrogen in a scrub-oak ecosystem exposed to elevated $\mathrm{CO}_{2}$. Soil Biol. Biochem. 41, 54-60. doi: 10.1016/j.soilbio.2008.09.016

Leuzinger, S., and Bader, M. K. F. (2012). Experimental vs. modeled water use in mature Norway spruce (Picea abies) exposed to elevated $\mathrm{CO}_{2}$. Front. Plant Sci. 3:229. doi: 10.3389/fpls.2012.00229

Luo, Y. Q., Su, B., Currie, W. S., Dukes, J. S., Finzi, A., Hartwig, U., et al. (2004). Progressive nitrogen limitation of ecosystem responses to rising atmospheric carbon dioxide. BioScience 54, 731-739. doi: 10.1641/00063568(2004)054[0731:PNLOER]2.0.CO;2

Lüthi, D., Le Floch, M., Bereiter, B., Blunier, T., Barnola, J.-M., Siegenthaler, U., et al. (2008). High-resolution carbon dioxide concentration record 650,000800,000 years before present. Nature 453, 379-382. doi: 10.1038/nature 06949

McCarthy, H. R., Oren, R., Johnsen, K. H., Gallet-Budynek, A., Pritchard, S. G., Cook, C. W., et al. (2010). Re-assessment of plant carbon dynamics at the Duke free-air $\mathrm{CO}_{2}$ enrichment site: interactions of atmospheric $\left[\mathrm{CO}_{2}\right]$ with nitrogen and water availability over stand development. New Phytol. 185, 514-528. doi: 10.1111/j.1469-8137.2009.03078.x

Meier, I. C., Finzi, A. C., and Phillips, R. P. (2017). Root exudates increase N availability by stimulating microbial turnover of fast-cycling $\mathrm{N}$ pools. Soil Biol. Biochem. 106, 119-128. doi: 10.1016/j.soilbio.2016.12.004 
Mellert, K. H., and Göttlein, A. (2012). Comparison of new foliar nutrient thresholds derived from van den Burg's literature compilation with established central European references. Euro. J. Forest Res. 131, 1461-1472. doi: 10.1007/s10342-012-0615-8

Nie, M., Lu, M., Bell, J., Raut, S., and Pendall, E. (2013). Altered root traits due to elevated $\mathrm{CO}_{2}$ : a meta-analysis. Glob. Ecol. Biogeogr. 22, 1095-1105. doi: 10.1111 /geb.12062

Norby, R. J., Ledford, J., Reilly, C. D., Miller, N. E., and O'Neill, E. G. (2004). Fine-root production dominates response of a deciduous forest to atmospheric $\mathrm{CO}_{2}$ enrichment. Proc. Natl. Acad. Sci. U. S. A. 101, 9689-9693. doi: 10.1073/pnas.0403491101

Norby, R. J., Warren, J. M., Iversen, C. M., Medlyn, B. E., and McMurtrie, R. E. (2010). $\mathrm{CO}_{2}$ enhancement of forest productivity constrained by limited nitrogen availability. Proc. Natl. Acad. Sci. U. S. A. 107, 19368-19373. doi: 10.1073/pnas.1006463107

Norman, R. J., and Stucki, J. W. (1981). The determination of nitrate and nitrite in soil extracts by ultraviolet spectrophotometry. Soil Sci. Soc. Am. J. 45, 347-353. doi: 10.2136/sssaj1981.03615995004500020024x

Ochoa-Hueso, R., Hughes, J., Delgado-Baquerizo, M., Drake, J. E., Tjoelker, M. G., Piñeiro, J., et al. (2017). Rhizosphere-driven increase in nitrogen and phosphorus availability under elevated atmospheric $\mathrm{CO}_{2}$ in a mature Eucalyptus woodland. Plant Soil 416, 283-295. doi: 10.1007/s11104-017-3212-2

OFEV (Office fédéral de l'environnement) (2005) Les Polluants Atmosphériques Azotés en Suisse. Rapport de la Commission Fédérale de L’hygiène de L'air. Cahier de L'Environnement No 384, Berne: OFEV.

Oren, R., Ellsworth, D. S., Johnsen, K. H., Phillips, N., Ewers B. E., Maier, C., et al. (2001). Soil fertility limits carbon sequestration by forest ecosystems in a $\mathrm{CO}_{2}$-enriched atmosphere. Nature 411,469-472. doi: 10.1038/35078064

Pepin, S., and Körner, C. (2002). Web-FACE: a new canopy Free-Air $\mathrm{CO}_{2}$ Enrichment system for tall trees in mature forests. Oecologia 133, 1-9. doi: 10.1007/s00442-002-1008-3

Phillips, R. P., Finzi, A. C., and Bernhardt, E. S. (2011). Enhanced root exudation induces microbial feedbacks to $\mathrm{N}$ cycling in a pine forest under longterm $\mathrm{CO}_{2}$ fumigation. Ecol. Lett. 14, 187-194. doi: 10.1111/j.1461-0248.2010. 01570.x

Phillips, R. P., Meier, I. C., Bernhardt, E. S., Grandy, A. S., Wickings, K., and Finzi, A. C. (2012). Roots and fungi accelerate carbon and nitrogen cycling in forests exposed to elevated $\mathrm{CO}_{2}$. Ecol. Lett. 15, 1042-1049. doi: 10.1111/j.1461-0248.2012.01827.x

Rollinson, C. R., Liu, Y., Raiho, A., Moore, D. J. P., McLachlan, J., Bishop, D. A., et al. (2017). Emergent climate and $\mathrm{CO}_{2}$ sensitivities of net primary productivity in ecosystem models do not agree with empirical data in temperate forests of eastern North America. Glob. Change Biol. 23, 2755-2767. doi: $10.1111 /$ gcb. 13626
Schleppi, P., Bucher-Wallin, I., Hagedorn, F., and Körner, C. (2012). Increased nitrate availability in the soil of a mixed mature temperate forest subjected to elevated $\mathrm{CO}_{2}$ concentration (canopy FACE). Glob. Change Biol. 18, 757-768. doi: 10.1111/j.1365-2486.2011.02559.x

Schleppi, P., Bucher-Wallin, I., Saurer, M., Jäggi, M., and Landolt, W. (2006). Citric acid traps to replace sulphuric acid in the ammonia diffusion of dilute water samples for ${ }^{15} \mathrm{~N}$ analysis. Rapid Commun. Mass Spectr. 20, 629-634. doi: $10.1002 / \mathrm{rcm} .2351$

Schleppi, P., Klein, T., and Körner, C. (2019). Nitrogen availability under trees exposed to $\mathrm{CO}_{2}$ enrichment (FACE). EnviDat 74. doi: 10.16904/envidat.74

Shrestha, J., Niklaus, P. A., Pasquale, N., Huber, B., Barnard, R. L., Frossard, E., et al. (2014). Flood pulses control soil nitrogen dynamics in a dynamic river floodplain. Geoderma 228-229, 14-24. doi: 10.1016/j.geoderma.2013. 09.018

Sigurdsson, B. D., Medhurst, J. L., Wallin, G., Eggertsson, O., and Linder, S. (2013). Growth of mature boreal Norway spruce was not affected by elevated $\left[\mathrm{CO}_{2}\right]$ and/or air temperature unless nutrient availability was improved. Tree Physiol. 33, 1192-1205. doi: 10.1093/treephys/ tpt043

Stringlis, I. A., Yu, K., Feussner, K., de Jonge, R., van Bentum, S., van Verk, M. C., et al. (2018). MYB72-dependent coumarin exudation shapes root microbiome assembly to promote plant health. Proc. Natl. Acad. Sci. U. S. A. 115, E5213E5222. doi: 10.1073/pnas.1722335115

Van Groenigen, K. J., Osenberg, C. W., Terrer, C., Carrillo, Y., Dijkstra, F. A., Heath, J., et al. (2017). Faster turnover of new soil carbon inputs under increased atmospheric $\mathrm{CO}_{2}$. Glob. Change Biol. 23, 4420-4429. doi: $10.1111 /$ gcb. 13752

Walthert, L., Graf, U., Kammer, A., Luster, J., Pezzotta, D., Zimmermann, S., et al. (2010). Determination of organic and inorganic carbon, $\delta^{13} \mathrm{C}$, and nitrogen in soils containing carbonates after acid fumigation with HCl. J. Plant Nutr. Soil Sci. 173, 207-216. doi: 10.1002/jpln.2009 00158

Conflict of Interest: The authors declare that the research was conducted in the absence of any commercial or financial relationships that could be construed as a potential conflict of interest.

Copyright (c) 2019 Schleppi, Körner and Klein. This is an open-access article distributed under the terms of the Creative Commons Attribution License (CC BY). The use, distribution or reproduction in other forums is permitted, provided the original author(s) and the copyright owner(s) are credited and that the original publication in this journal is cited, in accordance with accepted academic practice. No use, distribution or reproduction is permitted which does not comply with these terms. 